\title{
Infrastructure Development and Competitiveness of MSMEs as Trigger to Increase the Economy of Palembang City
}

\author{
Emi Suwarni, Kristina Sedyastuti and A. HAidar Mirza \\ Universitas Bina Darma
}

\begin{abstract}
This research aims to develop a strategy to encourage Micro, Small and Medium Enterprises (MSMEs) to take advantage of market openess opportunities through the enactment of various programs and developments. One of the programs includes Asian Games event that will be held in next 2018 and Palembang City will participate as one of the host for this event. As one of the host, Palembang City has to prepare everything including a number of infrastructure development financed by the stateto support the event. The infrastructure project is one of the government programs that is built to carry out the nation's goal which is an equitable development across the nation. The infrastructure development becomes an example of the use of the state budget from the public tax to meet the needs of the community. The role of Palembang as a sporting host will not only develop the city's infrastructure but also it will promote the local culture and boost the social and economic community. Based on the Department of Trade Industry Cooperatives and Micro Small Medium Enterprises(Department Industri Kreatif dan Usaha Mikro Kecil Menengah), the growth of MSMEs in Palembang significantly increases for the past six years, and this growth also affects the employment opportunities which in the end it escalates the economic sector. The method used qualitative analysis using descriptive explorative approach by identifying data sharing and information about MSMEs. The results revealed that the MSMEs can emerge through an effective strategy such as capacity building improvement and human resource development that is supported by information technology (IT).
\end{abstract}

Keywords: Infra structure, empowerment of MSMEs, improvement of the economy.

\section{Introduction}

According to the Central Bureau of Statistics (BPS) of Palembang City, predicted the growth of Micro, Small and Medium Enterprises (MSMEs) in this year increased to 100 percent or reached 400 thousand perpetrators of MSMEs, from 200 thousand based on data from 2006 [1]. That, based on the economic census as of May $1^{\text {st }}$, in South Sumatra, from 7,200 officers who collected data to obtain data related to the number of existing business actors at the time. The survey results, all types of businesses participated in the survey, including online businesses and resellers are increasingly mushrooming support economic growth.

Micro, Small and medium entrepreneurs (MSMEs) in South Sumatera Province must learn about trade management, and business actors themselves must be smart in managing their business in order to continue to grow and develop. South Sumatera Provincial Government itself through the Department of Trade has done various steps, including training and fostering of MSMEs actors in order to grow and become a big business. Socialization Activity Increase Domestic Product Usage in Educational Sector, Small and Medium Small Scale Micro, Small and Medium Enterprise Electronic System, Technical Guidance for Micro, Small and Medium Enterprises (SMEs) and Socialization of Alcoholic Beverage Policy, E-Commerce and Modern Stores, this socialization is conducted so that MSMEs can grow by utilizing banking management and business development. Many things should be known by SMEs about trade, for that socialization is very big benefits, especially for the perpetrators of MSMEs. With the expectation, MSMEs can become the backbone of the economy. Where through socialization expected domestic trade activity can be improved through domestic trade transactions. In 
addition, the Ministry of Trade itself continues to make efforts to encourage small and medium-sized enterprises to increase their activities through local-scale exhibitions.

The Ministry of Trade is currently drafting a regulation on networks and electronic or online media trade transactions. There will be four thingswill be regulated, such as how a business actor must have an identity with registers through online, traded products must meet the applicable provisions, clarity of financing system, and encourage new entrepreneurs through franchise system approach to how the business owned can continue to grow. To encourage the development of this MSMEs, The Ministry of Trade has cooperated with Bank BRI to cooperate. All this will be framed into one with the name of the online contract, with the socialization will occur synergy between the three Directorates of which the Directorate of Small and Medium Business and Domestic Products, Directorate of Business Development Trade, and Directorate of Domestic Trade. As many as 31,344 units of business are the majority of micro and small businesses that reach 26,653 units while the middle classification of 4,691 units.

The rapid growth of micro small and medium enterprises according to him, certainly able to encourage the improvement of local urban community economy, because it managed to absorb 18,876 people micro-special labor reached 6,186 units with a turnover of not less than Rp295, 03 billion and assets of about Rp73 billion. While small businesses reached 20,467 units and absorb 86,224 workers with a turnover above Rp 9 trillion and assets of Rp2, 5 trillion. While the middle business is 4,691 units and absorbs 21,838 workers with a turnover of more than Rp 13 trillion and assets reach Rp 4 trillion, tens of thousands of small and medium-sized micro enterprises are engaged in nine economic sectors of trade, services, manufacturing, agriculture, animal husbandry, finance, and communications. In addition, there is also a move in the field of building, electricity, gas and mining and excavation, empowerment efforts, especially on micro and small businesses continue to be done with continuous and sustainable development.

The Efforts to encourage economic growth through the development of micro and small priority enterprises continue to be done, it becomes one of the government programs to encourage the creation of a prosperous and economically independent society, not only facilitate the distribution of capital assistance that must be done local government, efforts the creation of a prosperous and economically self-sufficient society, not only to facilitate the distribution of capital assistance to be carried out by local municipal government, efforts to expand the business by marketing the products produced by small industries are also implemented. With the target, one day it will not be a product that is difficult to market because promotion and packing training has also been done optimally.

\section{Literature Review}

SMEs have special characteristics that distinguish them from large business types, including characteristics that differentiate micro, small and medium enterprises themselves. Based on data from BPS (2006) cited by Tambunan (2009) in the book of MSMEs in Indonesia, it is known that in terms of labor, more than one third (about 34.5 percent) SMEs managed by workers aged over 45 years, and only about 5.2 percent of MSMEs entrepreneurs aged under 25 years [2].

The labor required by small industries does not require high formal education. Most of the workforce required by this industry is based on the experience (learning by doing) associated with the historical factor (path dependence). Tambunan's (2009) advanced article on MSME revealed that the entrepreneur structure according to the level of formal education gives the impression of a positive relationship between the average level of business education and business scale. That is, the greater the scale of business, which generally associates positively with the level of business complexity that requires high skills and broader business insight, more and more entrepreneurs with tertiary formal education[3].

Referring to BPS (2006) data cited Tambunan (2009) it is known that most MSMEs entrepreneurs disclose the reason that their business activities are economic background. This means the business is done as an effort to obtain income improvements and or is a strategy for survival. This is supported by the low education level of 
entrepreneurs. This effort is done on the grounds that there are no other types of work that can be done with a relatively low level of formal education. Some entrepreneurs are also running a business taking into account future business prospects, such as the opportunity and market share of a safe and large. Others, however, reveal hereditary background, meaning continuing family heritage efforts.

BPS (2006) data also shows that Indonesia has many SMEs, but not all of these SMEs are legal entities. Precisely most of the existing MSMEs, which is about 95.1 percent of the total business units are not legal entities. This is acceptable for the reason that most MSMEs have very little capital and are bumped by various bureaucracy and complicated and complex requirements to get services in the development of their business.

According Sulistyastuti (2004), which is also a characteristic of MSMEs is the use of local raw materials. The existence of MSMEs is often related to the high intensity of local raw materials usage, for example, MSMEs handicrafts carving Jepara carving, batik from Pekalongan and various other local superior commodities used as raw materials in the business.

\section{Research Methodology}

This research uses descriptive explorative approach by knowing thestrategy of increasing competitiveness of sector of MSMEs and cooperative in facing Asian Economic Community (AEC). This research using literature review approach or literature study. The approach of theory or concept is done by referring from several sources, such asbooks, scientific journals, and the internet. All existing ideas are combined in a single frame of thought.

\section{Results and Discussion}

\subsection{Infrastructure Development}

Development of infrastructure in the province of South Sumatra is currently massive done. Not only to complete the construction of toll roads that are part of the Trans Sumatra Toll Road, the PUPR Ministry also builds other infrastructure including sports venues and athletes' homes to support the Asian Games in 2018. Currently, the PUPR Ministry is also preparing the Tiga dihaji Dam development targeted to begin construction in 2017. The dam will have a capacity of 260 million $\mathrm{m} 3$ to irrigate a new irrigation area of 25,000 hectares, raw water of $1 \mathrm{~m} 3$ per second, reduce flooding and potentially generate electricity. The construction budget is estimated to reach $\mathrm{Rp} 50$ billion.

Connectivity in South Sumatra is also being boosted by the government. A total of five toll roads of the Trans Sumatera Toll Road are being built in Sumsel, namely Palembang-Indralaya Toll road, Toll Terbanggi Besar-Pematang Panggang, Toll Pematang Panggang-Kayu Agung, Toll Palembang-Tanjung Api-Api Toll, and Toll Kayu Agung-Betung trough Palembang.

For drinking water, sanitation and slums, the PUPR Ministry through the Directorate General of Human Settlements through a labor-intensive program to enable communities to participate in development targeting 276 villages for Community Based Drinking and Sanitation (PAMSIMAS) activities. On a Community Based Sanitation Program (Sanimas) or improvement program Community-based (Sanimas) or environmental quality improvement program in sanitation and wastewater management is done in two urban villages with a fund of Rp 800 million. Program City without Slum (Kotaku) in South Sumatra conducted in 307 kelurahan at a cost of Rp 5.4 billion.

The Ministry of PUPR is also preparing access roads connecting villages to support the socio-economic activities of the community by empowering the community. This activity is carried out with coverage of 62.21 hectares in 11 villages at a cost of Rp 15 billion. In the housing sector, the PUPR Ministry will build self- 94 units and 3,000 housing units will be upgraded. For these two activities, the required funds reached Rp 56.07 billion. In addition, the apartment will be built for 97 units of MBR at a cost of Rp 34.3 billion. 
In addition to the sports arena of the Ministry of PUPR has prepared Wisma Jakabaring Athlete, as many as five towers (tower). A total of three towers have been completed in 2015, while currently being completed two more towers whose physical progress has reached 96.6 percent with a budget of $\mathrm{Rp} 41$ billion.

\subsection{Working Capital of MSMEs}

The biggest problem Small and medium-sized entrepreneurs they face is financial problems. They complain about the shortage of fixed capital and working capital. Another area that also creates many difficulties is credit for consumers. In many ways, for the progress and development of MSMEs, the government and various financial institutions, both banks and non-bank financial institutions have been working in providing services, especially in the case of business capital loans. But in fact, to access this service, MSMEs are burdened with long and complicated requirements and bureaucratic paths[4]. As a result, the provision of capital and credit services became inaccessible to MSMEs optimally. In essence, credit system improvements need to be pursued through the provision of professional mentoring services as well as the provision of credit that is integrated with other interventions to overcome the inhibiting factors of small business development itself[5].

\section{3. Market and Information Access}

Distrust of the ability of MSMEs in facing the era of globalization oriented to the free market mechanism is quite reasonable, because of the limitations that exist within the group. However, it should be remembered that since the era of colonization, MSMEs has been faced and forged with various problems including from the marketing aspect, but MSMEs still exist in support of the national economy. The incapability of MSMEs to face global markets may arise because of the lack of access to information[6][7].

Clapham (1991) states that there is a lack of capable information suppliers for small and medium sized companies. Companies find it difficult to gain entry into the government market because they are less aware of the intricacies of related government regulations or government requirements. The weak ability of MSMEs in accessing information allegedly directly related to the condition of internal factors of MSMEs overshadowed by various limitations to be able to provide information to the consumer. As a result, the actual MSME products have a considerable market share in the international world, not yet known to many consumers. One of the major problems faced in the empowerment of MSMEs is the low access of MSMEs to the market[8].

\subsection{MSMEs Marketing Condition}

The level of openness in the consumer market is low because the company does not have enough opportunities in the general public and so far only a few special trade shows, regular exhibitions or sales campaigns have ever been held. Domestic consumers, especially in urban areas, are often less aware of products produced by small and medium-sized domestic firms or are highly distrustful and prejudicial against these products when measured in accordance with international quality standards.

According to Sadoko (1995), marketing access is the most important access. In helping small businesses, this access is opened through the development of subcontracting patterns, mechanismscentral market information, market promotion or consumption through the government budget[9]. Promotion and information centre will be very useful if supported by the professional ability to read market opportunities for the small business and the service is provided for anyone. Agreed with this, Amidi (2008) also mentioned that the problem of marketing faced by MSMEs is the weakness of bargaining power of small entrepreneur in facing the big company[10].

The problem of marketing is one of the important causes why employers are not able to create medium and long-term plans. It can be expected that the marketing problems for small and medium entrepreneurs will increase. Overall, marketing issues resulted in small and medium-sized companies having difficulty playing their part in development as complementary to the industrial sector and suppliers of goods to consumers. Therefore, promotional programs in the future should pay more attention to marketing than in the past. 


\subsection{Increasing Competitiveness}

According to the Organization for Economic Co-Operation and Development (OECD) states that competitiveness is the ability of companies, industries, regions, countries, or inter-regions to generate income factors and work factors are relatively high and sustainable to face international competition. Because industrial competitiveness is a phenomenon at the micro level of the company, the national industrial development policy is preceded by assessing the industrial sector as a whole as the basis for measurement.

According to Tambunan, 2001, the competitiveness of a country in the international trade arena is basically determined by two factors: comparative advantage and competitive advantage. Furthermore, comparative factors of compensation can be considered as acquired or developed/created factors. In addition to these two factors, the competitiveness of a country is in fact also affected by what is called Sustainable Competitive Advantage (SCA) or the advantage of sustainable competitiveness. This is primarily in the framework of facing the level of global competition that is becoming increasingly tough or hyper-competitive.

Although Indonesia's infrastructure is still a lot of problems, in the last 5 years the progress is fast, especially the connectivity infrastructure. There are several facts proposed by the McKinsey Global Institute: that Indonesia today occupies the 16th rank of the world's economic power and is strongly likely to sit sweetly in the seventh strongest economic rankings in the world by 2030, and Indonesia has a rapidly growing population of young people in urban areas, this factor gives its own strength to increase state revenue. The above facts provide an enormous opportunity for creative economic actors in Indonesia. But it can also be a boomerang when the Indonesian government does not boost and support creative economic activities in Indonesia so feared potential consumers will be lured by creative products from abroad and in the end we only become a nation of consumers as we have experienced so far. Increased competitiveness with the use of information technology andthis communication is needed by local SME actors to face the increasingly tight business competition. Therefore, SMEs can use the technology as much as possible.

\section{Conclusion}

Strategy to develop Micro, Small and Medium Enterprises (MSMEs) in Indonesia can not be separated from banking support in lending. Currently, the credit scheme that is very familiar in the community is the People's Business Credit (KUR), which is specifically intended for MSMEs with the category of business feasible, without collateral. In addition, strengthening of MSMEs escort institutions can be done through ease of access and capacity building in the form of training and research activities that support the provision of credit to MSMEs.

The strategy to anticipate the increasingly open and competitive market mechanism especially in the Asian region is the control of the market, which is a prerequisite to improve the competitiveness of MSMEs. To be able to dominate the market, SMEs need to get information easily and quickly, both information about production market and production factor market to expand marketing network of products produced by MSMEs.

Information technology applications in micro, small and medium enterprises will facilitate SMEs in expanding the market both domestically and overseas markets efficiently. The establishment of IT-based MSMEs Development Centre is considered capable of encouraging the growth and development of micro, small and medium enterprises in the current information technology era.

\section{Acknowledgements}

We thank the Directorate General of Research Strengtening and Development under the Ministry of Research, Technology and Higher Education-Indonesia (RISTEKDIKTI-Indonesia) that provided the research grant. 


\section{References}

[1] Raden Moh.d. Solehin, 2017. BPS Memprediksi Pertumbuhan UMKM di Palembang Meningkat 100 persen, Kantor Berita RMOL Sumsel [Online]. Available: http://www.rmolsumsel.com/read/2016/05/04/50271/BPS-MemprediksiPertumbuhan-UMKM-di-Palembang-Meningkat-100-Persen-

[2] Tambunan, Tulus T.H., UMKM di Indonesia. Ghalia Indonesia. Jakarta. 2009.

[3] Sulistyastuti, Dyah Ratih, (2004). Dinamika Usaha Kecil dan Menengah (UKM): Analisis Konsentrasi Regional UKM di Indonesia 1999-2001. Jurnal Ekonomi Pembangunan, Volume 9, Nomor 2 Desember 2004, Available: http://journal.uii.ac.id/index.php/JEP/article/view/617/543 accessed 30 ${ }^{\text {th }}$ Juni 2017.

[4] Clapham, Ronald,. Pengusaha Kecil dan Menengah di Asia Tenggara. Translated by Masri Maris. Lembaga Penelitian, Pendidikan, dan Penerangan Ekonomi dan Sosial. Jakarta. 1991.

[5] Husen, Amran. Perekonomian Indonesia: Strategi Penguatan Usaha Mikro, Kecil, dan Menengah". Bayu Media Publishing- Malang. 2006.

[6] Syarif, Teuku, (2008). Kajian Efektivitas Model Promosi Pemasaran Produk UMKM. http://www.smecda.com/kajian/files/Jurnal_3_2008/01_T.Syarif.pdf. diunduh tanggal 3Juni 2017.

[7] Ishak, Effendi. (2005). Artikel : Peranan Informasi Bagi Kemajuan UKM. Kedaulatan Rakyat. Yogyakarta.

[8] Rahman, Arief. (2008). Small and Medium Enterprises (SMEs), Advanced Information on Small and Medium Enterprises (online), (http://infoukm.wordpress.com, accessed $1^{\text {st }}$ Juni 2017).

[9] Sadoko, et al., (1995). Pengembangan Usaha Kecil: Pemihakan Setengah Hati. Yayasan Akatiga. Bandung.

[10] MZ. Yasin, Intan Yanuarisma. Sinergi industry dan UMKM Berbasis Kelembagaan Dalam Meningkatkan Daya Saing Industri Nasional: Skema Implementasi dan Transmisi, Jurnal Ilmu Ekonomi Terapan, Desember 2016; 01 (2), ISSN 2085-461.7 available: https://e-journal.unair.ac.id/index.php/JIET/article/download/3276/2511 